\title{
The Controlled Introduction of Multiple Negative Charge at Single Amino Acid Sites in Subtilisin Bacillus lentus
}

\author{
Benjamin G. Davis, ${ }^{a}$ Xiao Shang, ${ }^{a}$ Grace DeSantis, ${ }^{a}$ Richard R. Bott ${ }^{b}$ and \\ J. Bryan Jones ${ }^{\mathrm{a}, *}$

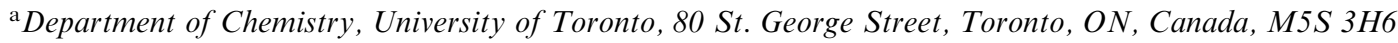 \\ ${ }^{\mathrm{b}}$ Genencor International, Inc., 925 Page Mill Rd., Palo Alto, CA 94304-1013, USA \\ Received 25 February 1999; accepted 6 April 1999
}

\begin{abstract}
The use of methanethiosulfonates as thiol-specific modifying reagents in the strategy of combined site-directed mutagenesis and chemical modification allows virtually unlimited opportunities for creating new protein surface environments. As a consequence of our interest in electrostatic manipulation as a means of tailoring enzyme activity and specificity, we have adopted this approach for the controlled incorporation of multiple negative charges at single sites in the representative serine protease, subtilisin Bacillus lentus (SBL). A series of mono-, di- and triacidic acid methanethiosulfonates were synthesized and used to modify cysteine mutants of SBL at positions 62 in the $S_{2}$ site, 156 and 166 in the $S_{1}$ site and 217 in the $S_{1}^{\prime}$ site. Kinetic parameters for these chemically modified mutant (CMM) enzymes were determined at $\mathrm{pH} 8.6$ under conditions which ensured complete ionization of the unnatural amino acid side-chains introduced. The presence of up to three negative charges in the $\mathrm{S}_{1}, \mathrm{~S}_{1}{ }^{\prime}$ and $\mathrm{S}_{2}$ subsites of $\mathrm{SBL}$ resulted in up to 11-fold lowered activity, possibly due to interference with oxyanion stabilization of the transition state of the hydrolytic reactions catalyzed. Each unit increase in negative charge resulted in a raising of $K_{\mathrm{M}}$ and a reduction of $k_{\text {cat }}$. However, no upper limit was observed for increases in $K_{\mathrm{M}}$, whereas decreases in $k_{\text {cat }}$ reached a limiting value. Comparison with sterically similar but uncharged CMMs revealed that electrostatic effects of negative charges at positions 62,156 and 217 are detrimental, but are beneficial at position 166. These results indicate that the ground-state binding of SBL to the standard substrate, Suc-AAPF$p N A$, to SBL is reduced, but without drastic attenuation of catalytic efficiency, and show that SBL tolerates high levels of charge at single sites. (C) 1999 Elsevier Science Ltd. All rights reserved.
\end{abstract}

\section{Introduction}

The introduction of charge into wild-type (WT) enzymes, through random ${ }^{1-3}$ or site-directed ${ }^{4-16}$ mutagenesis or chemical modification, ${ }^{17,18}$ can be used to broaden substrate specificity or to enhance catalytic activity. The successful tailoring of specificity towards charged substrates has confirmed the validity of exploiting the electrostatic attraction between complementary ions as a viable strategy for improving binding. For example, the introduction of negative charge into the active sites of subtilisin $\mathrm{BPN}^{\prime}{ }^{4}$ aspartate aminotransferase $^{6}$ and L-lactate dehydrogenase ${ }^{11}$ has expanded their structural specificities towards substrates with positively charged side chains.

Key words: Mutagenesis; electrostatic effects; enzymes and enzyme reactions; kinetics.

* Corresponding author. Tel.: + 1-416-978-3589; fax: + 1-416-9781553; e-mail: jbjones@alchemy.chem.utoronto.ca
Introductions of charge by protein engineering have typically been limited to naturally occurring amino acids such as negatively charged aspartate $e^{4,6,9,11-16}$ or positively charged arginine $e^{4,7,9}$ or lysine..$^{4,5,9,12}$ Chemical modification allows a greater variety of charged groups to be introduced, but the reactions used for their introduction are often non-specific in nature. ${ }^{19}$ For example, the reaction of cyclic anhydrides with trypsin caused indiscriminate modification of lysine residues, the effects of which could only be interpreted in general terms. ${ }^{17}$ Furthermore, although ingenious molecular biological techniques have been developed for the introduction of non-natural charged amino acids into proteins, ${ }^{20-22}$ they are not yet suitable for large-scale synthesis or routine application. In addition, the use of charged amino acids in such techniques can result in poor levels of incorporation. ${ }^{20,21}$

The use of site-directed mutagenesis combined with chemical modification ${ }^{23-28}$ of single sites offers a potential solution to these problems. In this technique cysteine is introduced at preselected positions and its 


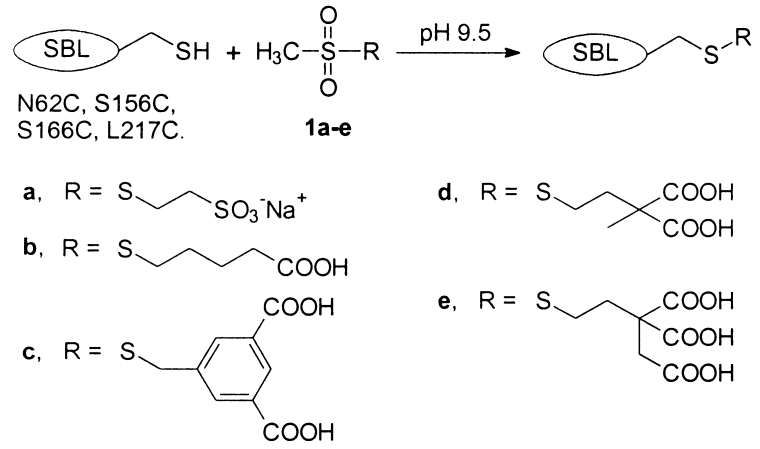

Scheme 1.

thiol residue is then reacted with methanethiosulfonate (MTS) reagents (Scheme 1). Methanethiosulfonate reagents react specifically and quantitatively with thiols. ${ }^{29,30}$ Recently, using the serine protease subtilisin Bacillus lentus (SBL) as our model, we have used this technique to improve enzyme activity ${ }^{31}$ and alter specificity. ${ }^{32,33}$ SBL is a near-ideal enzyme for evaluating the validity of this strategy since its does not contain a natural cysteine. In the current work we describe the use of this method to introduce locally high charge density into SBL through the incorporation of single residues bearing multiple charges.

Using the X-ray structure of $\mathrm{SBL}^{34}$ (Fig. 1) as our guide, four sites were chosen for mutation because of their seminal positions in the active site. Two of these, N62 (subtilisin $\mathrm{BPN}^{\prime}$ numbering) and L217, occupy positions that are equidistant from S221 of the catalytic triad, in the $\mathrm{S}_{2}{ }^{35}$ and $\mathrm{S}^{\prime}$ pockets, respectively. The other two sites, S156 and S166, are located at the base of the $S_{1}$ pocket and their side chains are directed towards SBL's surface and catalytic triad, respectively. The MTS reagents $1 \mathbf{a}-\mathbf{e}$ were selected to modify these positions.

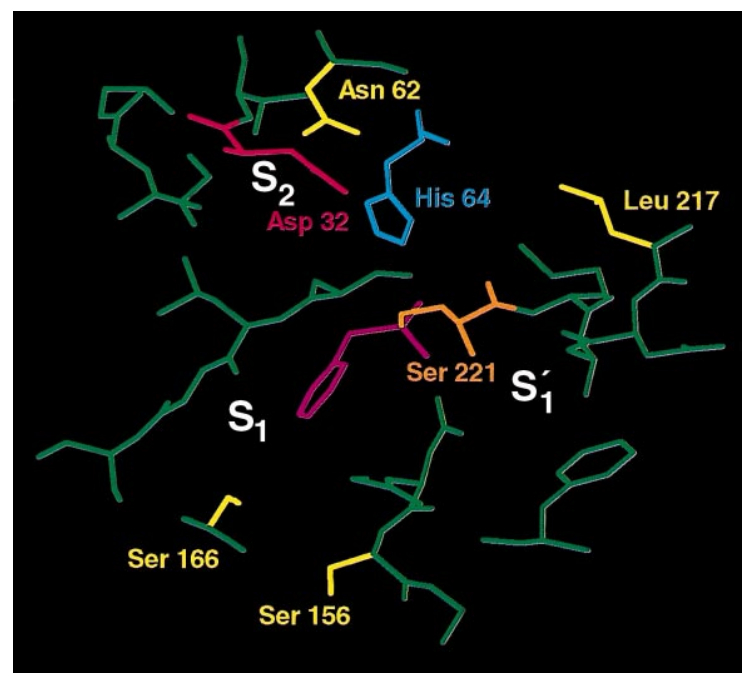

Figure 1. The active site of SBL showing the residues of the catalytic triad, Ser221 (orange), His64 (blue) and Asp32 (red). The irreversible phenylmethylsulfonyl inhibitor (pink) forms a bond to the $\mathrm{O} \gamma$ atom of Ser221 and its phenyl ring occupies the $\mathrm{S} 1$ binding site. The residues chosen for mutation, Asn62 in the $S_{2}$ site, Ser156 and Ser166 in the $S_{1}$ site and Leu217 in the $\mathrm{S}_{1}{ }^{\prime \prime}$ site are highlighted in yellow. ${ }^{34}$

\section{Results and Discussion}

Synthesis of carboxyalkyl methanethiosulfonates $1 \mathrm{~b}-\mathrm{e}$

Previous work 29,31 has demonstrated that, of the methods available, ${ }^{36-41}$ direct nucleophilic displacement of a primary alkyl bromide by methanethiosulfonate ion provides the most efficient method for the preparation of alkyl methanethiosulfonates. This general method was therefore adopted as the basis for the preparation of all of $\mathbf{1 b}-\mathbf{e}$. The aliphatic monocarboxylate MTS $\mathbf{1 b}^{42}$ was prepared from 5-bromopentanoic acid and $\mathrm{NaS}$ $\mathrm{SO}_{2} \mathrm{CH}_{3}$ in $80 \%$ yield.

The aromatic dicarboxylate MTS 1c was prepared from toluene-3,5-dicarboxylic acid (2) via a precursor benzylic bromide $\mathbf{3}$ as shown in Scheme 2. Treatment of 3 with $\mathrm{NaSSO}_{2} \mathrm{CH}_{3}$ gave the protected aromatic MTS 4 in $60 \%$ yield. Hydrolysis of $\mathbf{4}$ with TFA gave 1c as a white solid (91\% yield, $44 \%$ overall yield from 2 ).

The aliphatic di- and tricarboxylates 1d,e were prepared from Meldrum's acid (5a) using 1,2-dibromoethane to introduce a brominated linker group as shown in Scheme 3. The low $\mathrm{pK}_{\mathrm{a}}$ of $\mathbf{5 \mathbf { a } ^ { 4 3 , 4 4 }}$ allowed the use of mildly basic conditions compatible with this choice of linker. For the sake of simplicity, we chose methyl Meldrum's acid (5b) as a starting material for $\mathbf{1 d}$ in which one alkylation site is blocked as a methyl group. ${ }^{45}$ The synthesis of 1e utilized this position to introduce a third carboxylate moiety.

Alkylation of $\mathbf{5 b}$ with 1,2-dibromoethane afforded bromide $\mathbf{6 b}$ in $71 \%$ yield. Treatment of $\mathbf{6 b}$ with NaS$\mathrm{SO}_{2} \mathrm{CH}_{3}$ in DMF at $50^{\circ} \mathrm{C}$ led to the displacement of the remaining bromide and resulted in the formation of protected dicarboxylate MTS 7b. Hydrolysis of 7b using acidic ion exchange resin allowed the successful formation of the aliphatic diacidic MTS 1d (79\% yield, 37\% overall yield from $\mathbf{5 b}$ ).

The synthesis of the triacidic reagent 1e required the construction of a protected tricarboxylate $\mathbf{5 c}$ before

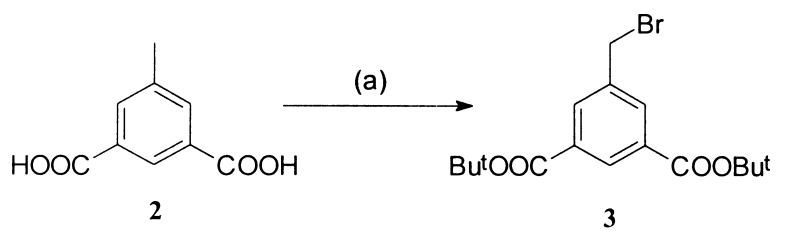

(b)

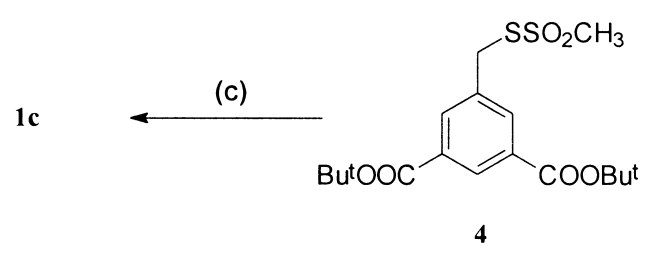

Scheme 2. (a) (i) $\operatorname{Im}_{2} \mathrm{CO}, \mathrm{DMF}, 40^{\circ} \mathrm{C}$ then $\mathrm{DBU}, t-\mathrm{BuOH}, 84 \%$, (ii) NBS, azobis(cyclohexanecarbonitrile), $\mathrm{CCl}_{4}, \Delta, 96 \%$; (b) NaS$\mathrm{SO}_{2} \mathrm{CH}_{3}, \mathrm{DMF}, 50^{\circ} \mathrm{C}, 60 \%$; (c) $\mathrm{CF}_{3} \mathrm{COOH}, \mathrm{CH}_{2} \mathrm{Cl}_{2}, 91 \%$. 
<smiles>[R]C1C(=O)OC(C)(C)OC1=O</smiles>

(a)

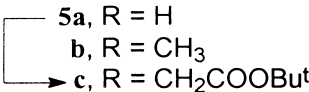

$1 d$

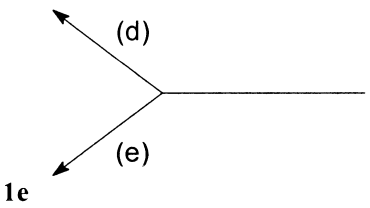<smiles>[R]C1(CCBr)C(=O)OC(C)(C)OC1=O</smiles>

6b, $\mathrm{R}=\mathrm{CH}_{3}$ c, $\mathrm{R}=\mathrm{CH}_{2} \mathrm{COOBu}$

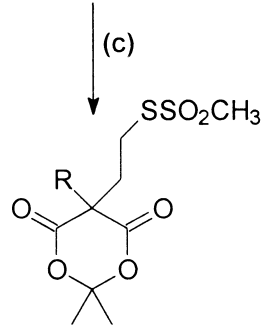

7b, $\mathrm{R}=\mathrm{CH}_{3}$

c, $\mathrm{R}=\mathrm{CH}_{2} \mathrm{COOBu}$
Scheme 3. (a) $\mathrm{K}_{2} \mathrm{CO}_{3}$, DMF then $\mathrm{BrCH}_{2} \mathrm{COOBu}$, 59\%; (b) $\mathrm{K}_{2} \mathrm{CO}_{3}$, DMF then $\mathrm{Br}\left(\mathrm{CH}_{2}\right)_{2} \mathrm{Br}, 71 \%$ for $\mathbf{6 b}, 66 \%$ for $\mathbf{6 c}$; (c) $\mathrm{NaSSO}_{2} \mathrm{CH}_{3}$, DMF, $50{ }^{\circ} \mathrm{C}, 83 \%$ for $\mathbf{7 b}, 86 \%$ for $7 \mathbf{c}$; (d) Dowex $50 \mathrm{~W}\left(\mathrm{H}^{+}\right)$, p-dioxane, $\mathrm{H}_{2} \mathrm{O}, 79 \%$; (e) $\mathrm{CF}_{3} \mathrm{COOD}, \mathrm{D}_{2} \mathrm{O}, 50^{\circ} \mathrm{C}, 70 \%$.

elaboration. Alkylation of Meldrum's acid (5a) with tert-butyl bromoacetate allowed the formation of $\mathbf{5 c}$ with moderate selectivity in $59 \%$ yield. Elaboration of tricarboxylate 5c was carried out using 1,2-dibromoethane and then $\mathrm{NaSSO}_{2} \mathrm{CH}_{3}$ in an analogous manner to that used for the synthesis of $\mathbf{1 d}$ and gave protected tricarboxylate MTS $7 \mathbf{c}$ in $57 \%$ yield over 2 steps. Complete deprotection of $7 \mathbf{c}$ using $\mathrm{CF}_{3} \mathrm{COOD}$ in $\mathrm{D}_{2} \mathrm{O}$ was followed by ${ }^{1} \mathrm{H}$ NMR, and resulted in the formation of target 1e ( $70 \%$ yield, $23 \%$ overall yield from $5 \mathbf{5 a})$.

\section{Preparation of chemically modified mutants (CMMs)}

MTS reagents 1a-e were used to modify the chosen SBL cysteine mutants, N62C, S156C, S166C and L217C under conditions described previously. ${ }^{31-33}$ These reactions proceeded rapidly and quantitatively, as judged by the monitoring of changes in specific activity and by titration of residual free thiols with Ellman's reagent, ${ }^{46}$ respectively. The structure of the charged CMMs was confirmed by ES-MS. Non-reducing native PAGE was used to determine the purity of all the enzymes, which appeared as single bands. Consistent with the introduction of negative charge, each of the CMMs showed retarded mobility in the direction of the cathode relative to WT. The active enzyme concentration of the resulting CMM solutions was determined by active site titration with $\alpha$-toluenesulfonyl fluoride (PMSF) using a fluoride ion-sensitive electrode. ${ }^{47}$

\section{Kinetic effects of site specific modification}

The effects of modification upon SBL were assessed by the determination of $k_{\mathrm{cat}}$ and $K_{\mathrm{M}}$ for the hydrolysis of succinyl-AAPF- $p$-nitroanilide (Suc-AAPF- $p$ NA). Our usual assay $\mathrm{pH}$ of 8.6 ensured complete ionization of the unnatural amino acid side-chains introduced. The kinetic parameters of the $20 \mathrm{CMMs}$ generated are compared with those of WT and unmodified mutants in Table 1 and Figure 2.

Table 1. Kinetic parameters ${ }^{\mathrm{a}}$ for modified enzymes

\begin{tabular}{|c|c|c|c|c|c|c|c|}
\hline Entry & Enzyme & Pocket & $\mathrm{R}$ & Level of charge & $k_{\text {cat }}\left(\mathrm{s}^{-1}\right)$ & $K_{\mathrm{M}}(\mathrm{mM})$ & $k_{\text {cat }} / K_{\mathrm{M}}\left(\mathrm{s}^{-1} \mathrm{mM}^{-1}\right)$ \\
\hline 1 & SBL-WT & - & - & - & $153 \pm 4$ & $0.73 \pm 0.05$ & $209 \pm 15$ \\
\hline 2 & N62C & $\mathrm{S}_{2}$ & $\mathrm{H}$ & 0 & $174 \pm 9$ & $1.90 \pm 0.20$ & $92 \pm 11$ \\
\hline 3 & & & a & 1 & $119 \pm 4$ & $0.93 \pm 0.07$ & $128 \pm 11$ \\
\hline 4 & & & b & 1 & $106 \pm 2$ & $1.01 \pm 0.05$ & $105 \pm 6$ \\
\hline 5 & & & c & 2 & $113 \pm 7$ & $1.00 \pm 0.10$ & $113 \pm 13$ \\
\hline 6 & & & d & 2 & $90 \pm 4$ & $1.47 \pm 0.14$ & $61 \pm 6$ \\
\hline 7 & & & e & 3 & $129 \pm 3$ & $1.46 \pm 0.06$ & $88 \pm 4$ \\
\hline 8 & L217C & $\mathrm{S}_{1}{ }^{\prime}$ & $\mathrm{H}$ & 0 & $41 \pm 1$ & $0.80 \pm 0.04$ & $51 \pm 3$ \\
\hline 9 & & & $\mathbf{a}$ & 1 & $89 \pm 6$ & $1.80 \pm 0.20$ & $50 \pm 6$ \\
\hline 10 & & & b & 1 & $54 \pm 1$ & $1.03 \pm 0.06$ & $52 \pm 3$ \\
\hline 11 & & & c & 2 & $69 \pm 2$ & $0.81 \pm 0.06$ & $85 \pm 7$ \\
\hline 12 & & & d & 2 & $63 \pm 2$ & $1.65 \pm 0.11$ & $38 \pm 3$ \\
\hline 13 & & & e & 3 & $55 \pm 2$ & $1.48 \pm 0.08$ & $37 \pm 3$ \\
\hline 14 & S156C & $\mathrm{S}_{1}$ & $\mathrm{H}$ & 0 & $125 \pm 4$ & $0.85 \pm 0.06$ & $147 \pm 11$ \\
\hline 15 & & & $\mathbf{a}$ & 1 & $87 \pm 2$ & $1.20 \pm 0.07$ & $73 \pm 5$ \\
\hline 16 & & & b & 1 & $76 \pm 1$ & $1.08 \pm 0.04$ & $70 \pm 3$ \\
\hline 17 & & & c & 2 & $61 \pm 1$ & $1.39 \pm 0.10$ & $44 \pm 3$ \\
\hline 18 & & & d & 2 & $53 \pm 1$ & $1.67 \pm 0.06$ & $32 \pm 1$ \\
\hline 19 & & & e & 3 & $74 \pm 2$ & $1.87 \pm 0.08$ & $39 \pm 2$ \\
\hline 20 & S166C & & $\mathrm{H}$ & 0 & $42 \pm 1$ & $0.50 \pm 0.05$ & $84 \pm 9$ \\
\hline 21 & & & $\mathbf{a}$ & 1 & $25 \pm 1$ & $1.34 \pm 0.08$ & $19 \pm 1$ \\
\hline 22 & & & b & 1 & $48 \pm 1^{b}$ & $1.52 \pm 0.06$ & $31 \pm 1^{b}$ \\
\hline 23 & & & c & 2 & $47 \pm 3$ & $1.60 \pm 0.20$ & $29 \pm 4$ \\
\hline 24 & & & d & 2 & $67 \pm 2$ & $2.26 \pm 0.10$ & $30 \pm 2$ \\
\hline 25 & & & e & 3 & $76 \pm 2$ & $2.46 \pm 0.11$ & $31 \pm 2$ \\
\hline
\end{tabular}

${ }^{a}$ Michaelis-Menten constants were measured at $25^{\circ} \mathrm{C}$ according to the initial rates method in $0.1 \mathrm{M}$ Tris- $\mathrm{HCl}$ buffer at $\mathrm{pH} 8.6,0.005 \% \mathrm{Tween} 80$, $1 \%$ DMSO, Suc-AAPF- $p$ NA as the substrate.

b Based on total protein concentration. ${ }^{48}$ 
Position 62 in the $S_{2}$ pocket is the most tolerant of mutation and modification (Fig. 2(a)) and mutation to cysteine reduces $k_{\text {cat }} / K_{\mathrm{M}}$ by only a factor of 2 (Table 1 , Entry 2). Upon modification, activity is partially restored and values of $k_{\text {cat }} / K_{\mathrm{M}}$ for $\mathrm{N} 62 \mathrm{C}-\mathbf{a}, \mathbf{b}, \mathbf{c}$ are raised approximately 1.5 -fold relative to N62C (Table 1, entries 3-5). Modifications with aliphatic di- and tricarboxylate MTS reagents 1d,e elicit further drops in $k_{\text {cat }} / K_{\mathrm{M}}$, with N62C-d being 3.5-fold lower than WT. However, despite the increased charge, this $k_{\text {cat }} / K_{\mathrm{M}}$ drop is less marked for N62C-e.
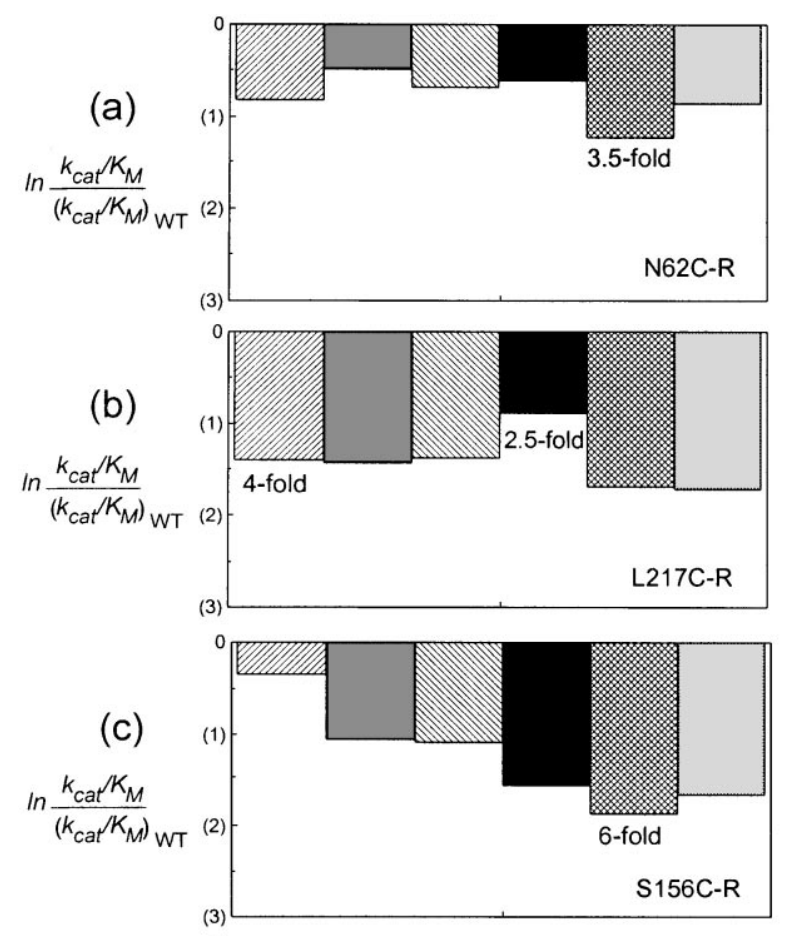

(d)

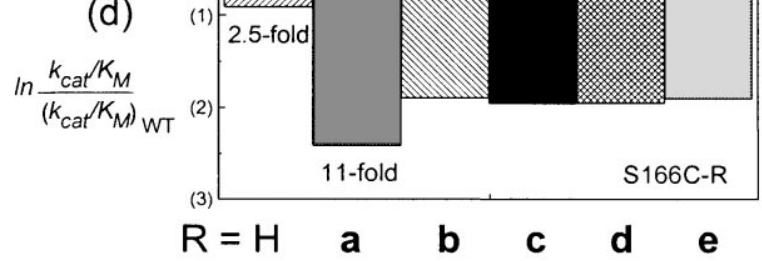

Figure 2. Altered specificity patterns relative to WT as the level of negative charge increases in N62C, L271C, S156C and S166C mutants and CMMs with suc-AAPF- $p \mathrm{NA}$ as the substrate: (a) The $k_{\text {cat }} / K_{\mathrm{M}} \mathrm{s}$ for $\mathrm{N} 62 \mathrm{C}$ CMMs alternate at moderately reduced levels, 1.5- to 3.5fold lower than WT, which are established by the initial mutation to N62C $(\mathrm{R}=\mathrm{H})$. (b) L217C CMMs show steady but lower levels of $k_{\text {cat }} /$ $K_{\mathrm{M}}$, 4- to 5.5-fold lower than WT, which are again established by the initial mutation to cysteine. The exception is L217C-c which is only 2.5 -fold lower than WT, possibly due to favourable binding of substrate to the phenyl ring of the aromatic side chain introduced by modification. (c) From the small reduction caused by mutation to S156C $(\mathrm{R}=\mathrm{H}), k_{\text {cat }} / K_{\mathrm{M}}$ s decrease monotonically to 6-fold lower than WT for S156C-d. The $\mathrm{k}_{\text {cat }} / K_{\mathrm{M}}$ of S156C-e is partially restored. (d) $k_{\text {cat }} /$ $K_{\mathrm{M}}$ decreases only 2.5 -fold upon mutation to $\mathrm{S} 166 \mathrm{C}(\mathrm{R}=\mathrm{H})$ but decreases dramatically to 11 -fold lower than WT when the negatively charged sulfonatoethyl side chain a is introduced. In parallel to N62C and L217C CMMs, $k_{\text {cat }} / K_{\mathrm{M}}$ for S166C CMMs does not decrease further to any significant extent as the level of negative charge increases.
The deleterious effect of negative charges in the $\mathrm{S}_{2}$ pocket upon $k_{\text {cat }}$ is apparent in the 1.3-fold decrease observed for N62C-a (Table 1, entry 3) relative to WT. However, as the level of negative charge increases, $k_{\text {cat }}$ values do not decrease further to any significant extent. In fact, of all the CMMs, the $k_{\text {cat }}$ level of N62C-e (129 $\mathrm{s}^{-1}$, Table 1, Entry 7) is the highest. In contrast, $K_{\mathrm{M}}$ values increase continually with each additional charge, reaching values for $\mathrm{N} 62 \mathrm{C}$-d (Table 1, Entry 6) and N62C-e (Table 1, Entry 7) that are 2-fold higher than WT.

The effects of mutation at position 217 in the $S_{1}{ }^{\prime}$ pocket (Fig. 2(b)) are intrinsically more dramatic than at all three other sites since the value of $k_{\text {cat }} / K_{\mathrm{M}}$ for $\mathrm{L} 217 \mathrm{C}$ is 4-fold lower than WT. The introduction of a single negative charge only affects $k_{\text {cat }} / K_{\mathrm{M}}$ a little and leads to near-identical $k_{\text {cat }} / K_{\mathrm{M}}$ values for L217C-a,b (Table 1, Entries 9,10). As negative charge increases further, two opposite trends are observed, with the $k_{\text {cat }} / K_{\mathrm{M}}$ value for aromatic $\mathrm{L} 217 \mathrm{C}$-c being raised 1.6 -fold relative to L217C-a,b, while those for aliphatic L217C-d,e are reduced by 1.4 -fold.

These slight $k_{\text {cat }} / K_{\mathrm{M}}$ changes seen at position 217 are the result of larger, but counteracting changes in each of $k_{\text {cat }}$ and $K_{\mathrm{M}}$. For example, while L217C-a has the highest value of $k_{\text {cat }}$, it also has the highest $K_{\mathrm{M}}$ value (both 2.2-fold higher than L217C). As at position 62, when the level of negative charge increases, from L217C-a to L217C-e, $k_{\text {cat }}$ values decrease only slightly and remain 1.3 - to 1.7 -fold higher than $\mathrm{L} 217 \mathrm{C}$ (Table 1, entries 10-13). $K_{\mathrm{M}}$ values increase unevenly to 2-fold higher than WT. Interestingly, the underlying cause of the out-of-line $k_{\text {cat }} / K_{\mathrm{M}}$ of L217C-c is an unusually low $K_{\mathrm{M}}(0.81 \mathrm{mM}$, entry 11$)$, which may be a consequence of complementary aromatic interactions between the substrate and the phenyl ring of side chain c.

The effects of mutation and modification at positions 156 and 166 in the $S_{1}$ pocket are shown in Figure 2(c) and (d). Mutation at position 156 to cysteine causes a 1.4-fold drop in $k_{\text {cat }} / K_{\mathrm{M}}(\mathrm{S} 156 \mathrm{C}$, Table 1, entry 14). From S156C-a to S156C-d $k_{\text {cat }} / K_{\mathrm{M}}$ decreases monotonically to a value that is 6-fold lower than WT. The additional negative charge present in S156C-e partially restores this value, to only 5.4 -fold lower than WT.

Mutation and modification at position 166 leads to the least active negatively charged CMMs, with $k_{\text {cat }} / K_{\mathrm{M}} \mathrm{s} 6$ to 11-fold lower than WT. This partly reflects the intrinsically lower $k_{\text {cat }} / K_{\mathrm{M}}$ value of the unmodified mutant S166C, which is already 2.5 -fold lower than WT. However, the presence of the sulfonatoethyl side chain in S166C-a causes a dramatic drop to a value that is 11 -fold lower than WT. $k_{\text {cat }} / K_{\mathrm{M}}$ is increased 1.5 -fold for $\mathrm{S} 166 \mathrm{C}-\mathbf{b}$ and remains steady as the level of negative charge increases from S166C-c to S166C-e.

The $k_{\text {cat }}$ values for $\mathrm{S} 156 \mathrm{C}$ and $\mathrm{S} 166 \mathrm{C}$ CMMs are similar to those found for $\mathrm{L} 217 \mathrm{C}$ CMMs, typically 2 to 
2.5-fold lower than WT. As at positions 62 and 217, the detrimental effect of a single negative charge on $k_{\text {cat }}$ is not amplified by the introduction of additional negative charges. In fact, $k_{\text {cat }}$ values for S166C CMMs increase steadily from 6-fold lower than WT for S166C-a (Table 1, entry 21) to 2-fold lower than WT for S166C-e (Table 1 , entry 25).

The $K_{\mathrm{M}}$ values for both $\mathrm{S} 156 \mathrm{C}$ and S166C CMMs increase steadily with increasing negative charge and are largest for S166C-e $\left(K_{\mathrm{M}} 2.46 \mathrm{mM}, 3.5\right.$-fold higher than WT, Table 1, entry 25). Consistent with its surfaceexposed nature these effects are less pronounced at position 156 , with $K_{\mathrm{M}}$ increasing to only 2.5 -fold higher than WT for S156C-e (Table 1, entry 19).

\section{Kinetic effects of negative charge}

To separate the contribution of electrostatics from steric effects, a comparison of these charged CMMs with those containing sterically similar uncharged side chains ${ }^{49}$ was made. For example, N62C-a was compared with $\mathrm{N} 62 \mathrm{C}-S$-ethyl, N62C-b,d,e were compared with N62C-S-n-pentyl and N62C-c was compared with $\mathrm{N} 62 \mathrm{C}-\mathrm{S}$-benzyl. Figure 3 illustrates the results of introducing charge to these near-isosteric systems. This provides an estimate of the effect of negative charge upon the kinetics of SBL when corrected for underlying steric and hydrophobic effects.

Two differing trends emerge from Figure 3. At positions 62, 217 and 156, the electrostatic contribution of each of side chains a-e is detrimental to $k_{\text {cat }} / K_{\mathrm{M}}$. The reductions caused are similar for each side chain, vary little from site to site and increase with the level of negative charge introduced. These reduced $k_{\mathrm{cat}} / K_{\mathrm{M}}$ values resulting from the introduction of negative charge are consistent with earlier findings. ${ }^{12,31-33}$ Such effects may be attributed, in part, to destabilization of the tetrahedral oxyanion intermediate that is formed in the rate limiting step of catalysis. ${ }^{50}$

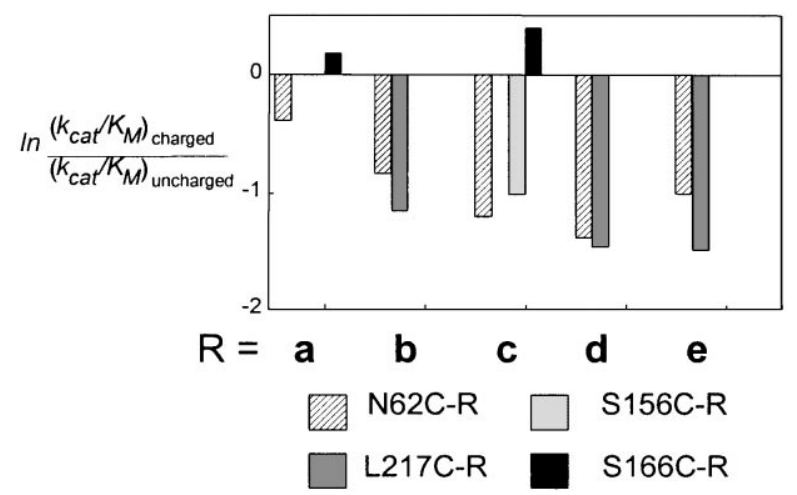

Figure 3. The effects of introducing negative charge to CMMs: $\ln$ $\left(k_{\text {cat }} / K_{\mathrm{M}}\right)$, with suc-AAPF- $p \mathrm{NA}$ as the substrate, of the negatively charged N62C, L217C and S156C CMMs decreases relative to that of near-isosteric uncharged $\mathrm{CMMs}$ as the level of negative charge increases (from side chain a to e). In contrast, this value for the corresponding S166C CMMs increases with increasing negative charge.
In contrast, the introduction of negative charge at position 166 partially restores some of the activity lost through the introduction of near-isosteric uncharged side chains. Therefore, the drastically lowered $k_{\text {cat }} / K_{\mathrm{M}} \mathrm{S}$ of CMMs S166C-a-e relative to WT are, in fact, a result of steric or hydrophobic effects. Mutation analysis of subtilisin $\mathrm{BPN}^{\prime}$ has shown that $k_{\text {cat }} / K_{\mathrm{M}}$ decreases dramatically when the optimal binding volume of the $\mathrm{S}_{1}$ pocket is exceeded.51 The effect of introducing even small groups at position 166 of $\mathrm{SBL}^{52}$ is to fill the $\mathrm{S}_{1}$ pocket and this dramatically decreases $k_{\text {cat }} / K_{\mathrm{M}}$. For example, uncharged CMM S166C-S-ethyl has a $k_{\text {cat }} / K_{\mathrm{M}}$ 13.5-fold lower than WT. ${ }^{49}$ Molecular mechanics analysis of S166C CMMs has shown that charged side chains introduced at position 166 may orientate themselves towards external solvent. ${ }^{33}$ This serves to reduce the volume of the $\mathrm{S}_{1}$ pocket that is occupied by the side chain. The existence of such an orientation for S166C$\mathbf{a}-\mathbf{e}$, which is lacking in uncharged CMM counterparts, might, in part, explain the beneficial effects of introducing charge. As a result, charged CMM S166C-S$\mathrm{EtSO}^{-}$, side chain a, has a $k_{\mathrm{cat}} / K_{\mathrm{M}}$ only 11 -fold lower than WT.

\section{Conclusions}

In summary, we have devised short and efficient synthetic routes to three novel multiply charged methanethiosulfonates, 1c, d and e. Such compounds, as well as being of interest in our approach to the controlled tailoring of enzyme activity, may prove useful in the study of ion channels. The use of MTS reagents in techniques such as the substituted-cysteine accessibility method (SCAM) $)^{53-55}$ has allowed aspects of membrane ion channel topology and conformation to be determined. In particular the use of charged MTS reagents has given an invaluable insight into ion specificity ${ }^{56}$ and mechanism of action. ${ }^{57-61}$

Using our established methodology, we selectively modified the cysteine thiols of SBL mutants, N62C, S156C, S166C, and L217C, with these reagents. Without exception, mutation and modification at all four sites led to reduced catalytic efficiency in the hydrolysis of Suc-AAPF- $p$ NA. However these reductions do not exceed 11-fold relative to WT and the lowest $k_{\mathrm{cat}}$ values determined were only 6-fold reduced. This reduced efficiency is manifested largely through decreased binding interactions, i.e. decreased $K_{\mathrm{M}}$ values, that increase with the level of charge introduced. In contrast, $k_{\text {cat }}$ values corresponding to the introduction of multiple charge are similar to, if not higher than, those for single charge. Comparison with near-isosteric uncharged CMMs revealed that electrostatic effects are important at positions 62, 217 and 156. However at position 166 steric effects dominate and the introduction of negative charge is, in fact, beneficial.

The hydrolysis of different substrates, including those containing basic residues, and $\mathrm{pH}$-activity profiles, are being investigated. The $\mathrm{p} K_{\mathrm{a}}$ effects and specificity consequences will be presented in due course. 


\section{Experimental}

Mutants of subtilisin Bacillus lentus (SBL) were generated, and WT and mutant enzymes purified as described previously. ${ }^{32,33} \mathrm{NaSSO}_{2} \mathrm{CH}_{3}$ (mp $269-269.5^{\circ} \mathrm{C}$ (dec.) (lit., ${ }^{29} \mathrm{mp} 272-273.5^{\circ} \mathrm{C}$ )) and toluene-3,5-dicarboxylic acid (2) ${ }^{62}$ (mp 294.5-296 ${ }^{\circ} \mathrm{C}$ (water) (lit., ${ }^{62} \mathrm{mp} 287-$ $288^{\circ} \mathrm{C}$ )) were prepared according to literature methods. DMF was distilled under $\mathrm{N}_{2}$ from $\mathrm{CaH}_{2}$ and stored over molecular sieves under $\mathrm{N}_{2}$ before use. $\mathrm{CCl}_{4}$ was fractionally distilled before use. Sulfonatoethyl methanethiosulfonate (1a) was purchased from Toronto Research Chemicals (2 Brisbane Rd., Toronto, ON, Canada). All other chemicals were used as received from Sigma-Aldrich or Baker. All flash chromatography was performed using silica gel (Whatman, $60 \AA$, 230-400 mesh). Melting points were determined using an Electrothermal IA9000 series digital melting point apparatus and are uncorrected. IR spectra were recorded on Bomem MB or Perkin-Elmer FTIR Spectrum 1000 spectrophotometers. ${ }^{1} \mathrm{H}$ NMR and ${ }^{13} \mathrm{C}$ NMR spectra were recorded on a Varian Gemini 200 NMR spectrometer at 200 and $50.3 \mathrm{MHz}$, respectively. ESMS data were acquired using a PE SCIEX API III Biomolecular mass spectrometer. All other MS and HRMS data, were acquired using Micromass $70-250 \mathrm{~S}$ or Micromass ZAB-SE mass spectrometers according to the ionization methods indicated. Microanalyses were performed by Canadian Microanalytical Service Ltd. (Delta, B.C., V4G 1G7, Canada). Solvents were removed in vacuo.

4-Carboxybutyl methanethiosulfonate (1b) ${ }^{42}$ A solution of 5-bromopentanoic acid (1.238 g, $6.84 \mathrm{mmol})$ and $\mathrm{NaSSO}_{2} \mathrm{CH}_{3}(0.916 \mathrm{~g}, 6.84 \mathrm{mmol})$ in DMF $(6 \mathrm{~mL})$ was heated at $70^{\circ} \mathrm{C}$ under $\mathrm{N}_{2}$. After $2 \mathrm{~h}$ the solution was cooled, water $(15 \mathrm{~mL})$ added and the resulting mixture extracted with ether $(30 \mathrm{~mL} \times 3)$. The organic fractions were combined, washed with brine, dried $\left(\mathrm{MgSO}_{4}\right)$, filtered and the solvent removed. The residue was purified by flash chromatography (ether: $\mathrm{CH}_{2} \mathrm{Cl}_{2}: \mathrm{AcOH}, 40$ : $120: 1)$ to give $\mathbf{1 b}(1.167 \mathrm{~g}, 80 \%)$ as a white solid; $\mathrm{mp}$ 61-62.5 $5^{\circ} \mathrm{C}$ [lit. ${ }^{42} \mathrm{mp} 69-71^{\circ} \mathrm{C}$; IR $(\mathrm{KBr}) 1703 \mathrm{~cm}^{-1}$ $(\mathrm{C}=\mathrm{O}), 1311,1125 \mathrm{~cm}^{-1}\left(\mathrm{~S}-\mathrm{SO}_{2}\right) ;{ }^{1} \mathrm{H}$ NMR $\left(\mathrm{CDCl}_{3}\right) \delta$ $1.70-2.00(\mathrm{~m}, 4 \mathrm{H}, \mathrm{H}-2, \mathrm{H}-3), 2.43(\mathrm{t}, J=6.9 \mathrm{~Hz}, 2 \mathrm{H}, \mathrm{H}-$ 4), $3.20(\mathrm{t}, J=6.8 \mathrm{~Hz}, 2 \mathrm{H}, \mathrm{H}-1), 3.34\left(\mathrm{~s}, 3 \mathrm{H}, \mathrm{SSO}_{2} \mathrm{CH}_{3}\right)$, $8.82($ br s, $1 \mathrm{H}, \mathrm{COOH}) ;{ }^{13} \mathrm{C} \mathrm{NMR}\left(\mathrm{CDCl}_{3}\right) \delta 23.4,28.9$, 33.1, $35.9\left(\left(\mathrm{CH}_{2}\right)_{4}\right), 50.7\left(\mathrm{SSO}_{2} \mathrm{CH}_{3}\right), 178.7(\mathrm{COOH})$; MS $m / z\left(\mathrm{EI}^{+}\right): 213\left(\mathrm{M}+\mathrm{H}^{+}, 2\right), 195\left(\mathrm{M}+\mathrm{H}^{+}-\mathrm{H}_{2} \mathrm{O}\right.$, 11), 133 (50), $115\left(\mathrm{M}^{+}-\mathrm{CH}_{3} \mathrm{SO}_{2}-\mathrm{H}_{2} \mathrm{O}, 100 \%\right)$; HRMS $m / z(\mathrm{EI}+)$ : Found $213.0251\left(\mathrm{M}+\mathrm{H}^{+}\right) ; \mathrm{C}_{6} \mathrm{H}_{13} \mathrm{O}_{4} \mathrm{~S}_{2}$ requires 213.0255.

3,5-Dicarboxybenzyl methanethiosulfonate (1c). 1,1'Carbonyldiimidazole $(6.67 \mathrm{~g}, 0.0411 \mathrm{~mol})$ was added to a solution of toluene-3,5-dicarboxylic acid (2) (3.364 g, $0.0187 \mathrm{~mol})$ in DMF $(30 \mathrm{~mL})$ and the resulting mixture stirred at $40^{\circ} \mathrm{C}$ under $\mathrm{N}_{2}$. After $1.5 \mathrm{~h}$ DBU $(6.15 \mathrm{~mL}$, $0.041 \mathrm{~mol})$ and $t$-BuOH $(7.7 \mathrm{~mL}, 0.0822 \mathrm{~mol})$ were added. After $24 \mathrm{~h}$ the solution was cooled, ether $(150$ $\mathrm{mL})$ added and the mixture acidified ( $\mathrm{HCl}(\mathrm{aq}), 1.5 \mathrm{M})$. The ethereal layer was separated and the aqueous layer further extracted (ether, $150 \mathrm{~mL}$ ). The organic fractions were combined, washed with water and $10 \% \mathrm{~K}_{2} \mathrm{CO}_{3}$ (aq), dried $\left(\mathrm{MgSO}_{4}\right)$, filtered and the solvent removed. The residue was purified by flash chromatography (EtOAc:hexane, 1:50) to afford a colorless oil which solidified upon standing to give di-tert-butyl toluene3,5-dicarboxylate $(4.58 \mathrm{~g}, 84 \%)$ as a white solid; $\mathrm{mp}$ 86.5-87.5 ${ }^{\circ} \mathrm{C}$ (hexane); IR (film) $1712 \mathrm{~cm}^{-1}(\mathrm{C}=\mathrm{O})$, $1606,1476 \mathrm{~cm}^{-1}(\mathrm{Ar} \mathrm{C}=\mathrm{C}) ;{ }^{1} \mathrm{H}$ NMR $\left(\mathrm{CDCl}_{3}\right) \delta 1.60(\mathrm{~s}$, $\left.18 \mathrm{H}, \mathrm{C}\left(\mathrm{CH}_{3}\right)_{3}\right), 2.43\left(\mathrm{~s}, 3 \mathrm{H}, \mathrm{CH}_{3}\right), 7.95$ (br s, $2 \mathrm{H}, \mathrm{H}-2$, $\mathrm{H}-6), 8.38$ (br s, $1 \mathrm{H}, \mathrm{H}-4) ;{ }^{13} \mathrm{C}$ NMR $\left(\mathrm{CDCl}_{3}\right) \delta 21.4$ $\left(\mathrm{CH}_{3}\right), 28.2\left(\mathrm{C}\left(\mathrm{CH}_{3}\right)_{3}\right), 81.4\left(\mathrm{C}\left(\mathrm{CH}_{3}\right)_{3}\right), 127.7,132.1$, 133.7, 138.1 (Ar), 165.2 (COO).

NBS (0.521 g, $2.93 \mathrm{mmol}$ ) and 1,1'-azobis(cyclohexanecarbonitrile) $(30 \mathrm{mg}, 0.12 \mathrm{mmol})$ were added to solution of this diester $(0.712 \mathrm{~g}, 2.44 \mathrm{mmol})$ in $\mathrm{CCl}_{4}(10$ $\mathrm{mL}$ ) and heated under reflux under $\mathrm{N}_{2}$. After $3 \mathrm{~h}$ a second portion of initiator ( $30 \mathrm{mg}, 0.12 \mathrm{mmol}$ ) was added. After a further $3 \mathrm{~h}$ the reaction solution was cooled and filtered. The filtrate was washed with sat. $\mathrm{NaHCO}_{3}(\mathrm{aq})$, dried $\left(\mathrm{MgSO}_{4}\right)$, filtered and the solvent removed. The residue was partially purified by flash chromatography (EtOAc:hexane, 1:50) to afford crude 3,5-di(tert-butoxycarbo)benzylbromide (3) $(0.872 \mathrm{~g}, 96 \%)$. A solution of 3 $(0.872 \mathrm{~g}, 2.35 \mathrm{mmol})$ and $\mathrm{NaSSO}_{2} \mathrm{CH}_{3}(0.327 \mathrm{~g}, 2.44$ mmol) in DMF $(1 \mathrm{~mL})$ was heated at $50^{\circ} \mathrm{C}$ under $\mathrm{N}_{2}$. After $1 \mathrm{~h}$ the reaction solution was cooled, diluted with water $(5 \mathrm{~mL})$ and extracted with ether $(15 \mathrm{~mL} \times 3)$. The combined extracts were washed with brine, dried $\left(\mathrm{MgSO}_{4}\right)$ and the solvent removed. The residue was purified by flash chromatography (EtOAc:hexane, 1:8) to give 3,5-di(tert-butoxycarbo)benzyl methanethiosulfonate (4) $(0.570 \mathrm{~g}, 60 \%)$ as a colorless oil; IR (film) $1717 \mathrm{~cm}^{-1}(\mathrm{C}=\mathrm{O}), 1604,1477,1456 \mathrm{~cm}^{-1}(\mathrm{Ar} \mathrm{C}=\mathrm{C})$, $1328,1135 \mathrm{~cm}^{-1}\left(\mathrm{~S}-\mathrm{SO}_{2}\right) ;{ }^{1} \mathrm{H}$ NMR $\left(\mathrm{CDCl}_{3}\right) \delta 1.59(\mathrm{~s}$, $\left.18 \mathrm{H}, \mathrm{C}\left(\mathrm{CH}_{3}\right)_{3}\right), 3.07\left(\mathrm{~s}, 3 \mathrm{H}, \mathrm{SO}_{2} \mathrm{CH}_{3}\right), 4.43(\mathrm{~s}, 2 \mathrm{H}$, $\left.\mathrm{CH}_{2}\right), 8.13(\mathrm{~s}, 2 \mathrm{H}, \mathrm{H}-2, \mathrm{H}-6), 8.48(\mathrm{~s}, 1 \mathrm{H}, \mathrm{H}-4) ;{ }^{13} \mathrm{C}$ NMR $\left(\mathrm{CDCl}_{3}\right) \delta 28.2\left(\mathrm{C}\left(\mathrm{CH}_{3}\right)_{3}\right), 40.0\left(\mathrm{CH}_{2}\right), 51.3$ $\left(\mathrm{SO}_{2} \mathrm{CH}_{3}\right), 82.1\left(\mathrm{C}\left(\mathrm{CH}_{3}\right)_{3}\right), 130.2,133.2,133.5,135.7$ (Ar), 164.3 (COO).

A solution of $4(0.941 \mathrm{~g}, 2.30 \mathrm{mmol})$ in $\mathrm{CF}_{3} \mathrm{COOH}$ : $\mathrm{CH}_{2} \mathrm{Cl}_{2}(1: 1 \mathrm{v} / \mathrm{v}, 10 \mathrm{~mL})$ was stirred at room temperature for $3 \mathrm{~h}$, during which time a white precipitate was formed. The solvents were removed and the residue triturated with $\mathrm{CH}_{2} \mathrm{Cl}_{2}(5 \mathrm{~mL})$. The resulting mixture was filtered, and the residue washed with $\mathrm{CH}_{2} \mathrm{Cl}_{2}$ and dried under vacuum to give 1c $(0.611 \mathrm{~g}$, $91 \%$ from 4$)$ as a white solid; $\mathrm{mp} 199.5-200\left({ }^{\circ} \mathrm{C}\right.$ (dec.); IR (KBr) 1716, $1693 \mathrm{~cm}^{-1}(\mathrm{C}=\mathrm{O}), 1605,1461 \mathrm{~cm}^{-1}(\mathrm{Ar}$ $\mathrm{C}=\mathrm{C}), 1319,1128 \mathrm{~cm}^{-1}\left(\mathrm{~S}_{-} \mathrm{SO}_{2}\right) ;{ }^{1} \mathrm{H}$ NMR (acetone- $\left.d_{6}\right)$ $\delta 3.29\left(\mathrm{~s}, 3 \mathrm{H}, \mathrm{SO}_{2} \mathrm{CH}_{3}\right), 4.69\left(\mathrm{~s}, 2 \mathrm{H}, \mathrm{CH}_{2}\right), 8.36(\mathrm{~d}$, $J=1.4 \mathrm{~Hz}, 2 \mathrm{H}, \mathrm{H}-2, \mathrm{H}-6), 8.61(\mathrm{t}, J=1.7 \mathrm{~Hz}, 1 \mathrm{H}, \mathrm{H}-4)$; ${ }^{13} \mathrm{C}$ NMR (acetone- $\left.d_{6}\right) \delta 40.0\left(\mathrm{CH}_{2}\right), 51.2\left(\mathrm{SO}_{2} \mathrm{CH}_{3}\right)$, $130.8,132.5,135.2,138.5(\mathrm{Ar}), 166.3(\mathrm{COOH}) ; \mathrm{MS} m / z$ $(\mathrm{EI}+): 290\left(\mathrm{M}^{+}, 2\right), 273\left(\mathrm{M}^{+}-\mathrm{OH}, 4\right), 210\left(\mathrm{M}^{+}\right.$. $\left.\mathrm{CH}_{3} \mathrm{SO}_{2} \mathrm{H}, 100\right), 179\left(\mathrm{M}^{+}-\mathrm{SSO}_{2} \mathrm{CH}_{3}, 5\right)$; HRMS $m / z$ $(\mathrm{FAB}+)$ : Found $290.9987\left(\mathrm{M}+\mathrm{H}^{+}\right), \quad \mathrm{C}_{10} \mathrm{H}_{11} \mathrm{O}_{6} \mathrm{~S}_{2}$ requires 290.9998 .

3,3-Dicarboxybutyl methanethiosulfonate (1d). Anhydrous $\mathrm{K}_{2} \mathrm{CO}_{3}(1.67 \mathrm{~g}, 12.0 \mathrm{mmol})$ was added to a solution of methyl Meldrum's acid $(\mathbf{5 b})(1 \mathrm{~g}, 6.33 \mathrm{mmol})$ in 
DMF (33 mL) under $\mathrm{N}_{2}$ and stirred vigorously. After 1 $\mathrm{h}$ the supernatant liquid was added dropwise to a solution of 1,2-dibromoethane $(1.9 \mathrm{~mL}, 22.2 \mathrm{mmol})$ in DMF (11 mL) under $\mathrm{N}_{2}$. After $89 \mathrm{~h}$ TLC (EtOAc:hexane, 1:3) indicated conversion of starting material $\left(R_{f} 0.3\right)$ to a major product $\left(R_{f} 0.5\right)$. The reaction mixture was added to water $(100 \mathrm{~mL})$ and extracted with ether $(100 \mathrm{~mL} \times$ 3). The organic fractions were combined, dried $\left(\mathrm{MgSO}_{4}\right)$, filtered and the solvent removed. The residue was purified by flash chromatography (EtOAc:hexane, $1: 4)$ to give 5-(2'-bromoethyl)-2,2,5-trimethyl-1,3-dioxocyclohexa-4,6-dione (6b) $(1.183 \mathrm{~g}, 71 \%)$ as a white solid; mp 84-85 $\mathrm{C}$ (ether:hexane); IR (KBr) 1738, $1784 \mathrm{~cm}^{-1}$ $(\mathrm{C}=\mathrm{O}) ;{ }^{1} \mathrm{H} \mathrm{NMR}\left(\mathrm{CDCl}_{3}\right) \delta 1.66\left(\mathrm{~s}, 3 \mathrm{H}, \mathrm{CH}_{3}\right), 1.76$, $1.78\left(\mathrm{~s} \times 2,3 \mathrm{H} \times 2, \mathrm{C}\left(\mathrm{CH}_{3}\right)_{2}\right), 2.61(\mathrm{t}, J=8 \mathrm{~Hz}, 2 \mathrm{H}, \mathrm{H}-$ $\left.1^{\prime}\right), 3.32\left(\mathrm{t}, J=8 \mathrm{~Hz}, 2 \mathrm{H}, \mathrm{H}-2^{\prime}\right) ;{ }^{13} \mathrm{C} \mathrm{NMR}\left(\mathrm{CDCl}_{3}\right) \delta$ 25.2, 26.6, 29.1, 30.1, $42.4\left(\mathrm{CH}_{3}, \mathrm{C}\left(\mathrm{CH}_{3}\right)_{2}, \mathrm{C}-1^{\prime}, \mathrm{C}-2^{\prime}\right)$, 49.4 (C-5), $106.0\left(\mathrm{C}\left(\mathrm{CH}_{3}\right)_{2}\right), 169.5(\overline{\mathrm{C}}-4, \mathrm{C}-6)$; MS m/z $(\mathrm{EI}+): 249,251\left(\mathrm{M}^{+}-\mathrm{CH}_{3}, 5\right), 206,208\left(\mathrm{M}^{+}-\mathrm{OC}\left(\mathrm{CH}_{3}\right)_{2}\right.$, 14), 162, $164\left(\mathrm{M}+-\mathrm{C}(\mathrm{O}) \mathrm{OCO}\left(\mathrm{CH}_{3}\right)_{2}, 42\right), 69(\mathrm{M}+-$ $\left.\mathrm{C}(\mathrm{O}) \mathrm{OCO}\left(\mathrm{CH}_{3}\right)_{2}-\mathrm{CH}_{2} \mathrm{Br}, 100 \%\right)$.

$\mathrm{NaSSO}_{2} \mathrm{CH}_{3}$ (776 mg, $5.80 \mathrm{mmol}$ ) was added to a solution of $\mathbf{6 b}(1.18 \mathrm{~g}, 4.46 \mathrm{mmol})$ in DMF (40 mL) under $\mathrm{N}_{2}$ and the resulting solution warmed to $50^{\circ} \mathrm{C}$. After $29 \mathrm{~h}$ the reaction solution was cooled and the solvent removed. The residue was purified by flash chromatography (EtOAc:hexane, 3:7 to give $2-\left(2^{\prime}, 2^{\prime}, 5^{\prime}\right.$-trimethyl1,3-dioxocyclohexa-4,6-dionyl)ethyl methanethiosulfonate (7b) $(1.10 \mathrm{~g}, 83 \%)$ as a cloudy oil; IR (film) 1737, 1771 $\mathrm{cm}^{-1}(\mathrm{C}=\mathrm{O}), 1300,1133 \mathrm{~cm}^{-1}\left(\mathrm{~S}-\mathrm{SO}_{2}\right) ;{ }^{1} \mathrm{H}$ NMR $\left(\mathrm{CDCl}_{3}\right) \delta 1.68\left(\mathrm{~s}, 3 \mathrm{H}, \mathrm{CH}_{3}\right), 1.78,1.79(\mathrm{~s} \times 2,3 \mathrm{H} \times 2$, $\left.\mathrm{C}\left(\mathrm{CH}_{3}\right)_{2}\right), 2.47-2.55$ (m, 2H, H-2), 3.08-3.16 (m, 2H, H1), $3.34\left(\mathrm{~s}, 3 \mathrm{H}, \mathrm{SSO}_{2} \mathrm{CH}_{3}\right) ;{ }^{13} \mathrm{C} \mathrm{NMR} \mathrm{CDCl}_{3} \delta 24.9$, $29.3,30.0,31.9,49.2\left(\mathrm{CH}_{3}, \mathrm{C}\left(\mathrm{CH}_{3}\right)_{2}, \mathrm{C}-1, \mathrm{C}-2\right), 49.2$ $\left.\left(\mathrm{C}-5^{\prime}\right), 51.2\left(\mathrm{SSO}_{2} \mathrm{CH}_{3}\right), 106.1 \overline{(\mathrm{C}}\left(\mathrm{CH}_{3}\right)_{2}\right), 169.5\left(\mathrm{C}-4^{\prime}\right.$, C-6'); $\mathrm{MS} m / z(\mathrm{EI}+)$ : $281\left(\mathrm{M}^{+}{ }_{-}-\mathrm{CH}_{3}, 1\right), 269$ (2), 239 $\left(\mathrm{M}^{+}-\mathrm{C}_{3} \mathrm{H}_{5} \mathrm{O}, 3\right), 159$ (100), 141 (56), 113 (96), 103 (23), 87 (78), $69\left(\mathrm{M}^{+}-\mathrm{C}(\mathrm{O}) \mathrm{OCO}\left(\mathrm{CH}_{3}\right)_{2}-\mathrm{CH}_{2} \mathrm{SSO}_{2} \mathrm{CH}_{3}\right.$, $79 \%$ ).

Dowex $50 \mathrm{~W}\left(\mathrm{H}^{+}\right)$resin $(2.53 \mathrm{~g})$ was added to a suspension of $7 \mathbf{b}(1.08 \mathrm{~g}, 3.65 \mathrm{mmol})$ in $p$-dioxan $(3.5 \mathrm{~mL})$ and distilled water $(35 \mathrm{~mL})$ and stirred at room temperature. After $68 \mathrm{~h}$ the reaction mixture was filtered and the solvent removed. The resulting solid was recrystallized from water:acetone:ethyl acetate to give 1d (738 mg, $79 \%$ ) as a white solid; $\mathrm{mp} 109-111^{\circ} \mathrm{C}$; IR (KBr) 1706 $\mathrm{cm}^{-1}(\mathrm{C}=\mathrm{O}), 1317,1133 \mathrm{~cm}^{-1}\left(\mathrm{~S}_{-} \mathrm{SO}_{2}\right) ;{ }^{1} \mathrm{H} \mathrm{NMR}\left(\mathrm{D}_{2} \mathrm{O}\right)$ $\delta 1.43(\mathrm{~s}, 3 \mathrm{H}, \mathrm{H}-4), 2.25-2.33(\mathrm{~m}, 2 \mathrm{H}, \mathrm{H}-2), 3.16-3.24$ (m, 2H, H-1), 3.45 (s, 3H, $\left.\mathrm{SSO}_{2} \mathrm{CH}_{3}\right) ;{ }^{13} \mathrm{C}$ NMR $\left(\mathrm{D}_{2} \mathrm{O}\right)$ $\delta 20.3$ (C-4), 32.1, 36.4 (C-1, C-2), $50.5\left(\mathrm{SSO}_{2} \mathrm{CH}_{3}\right), 54.3$ (C-3), $176.0(\mathrm{COOH}) ; \mathrm{MS} m / z(\mathrm{EI}+): 256\left(\mathrm{M}^{+}, 6\right), 132$ $\left(\mathrm{M}+\mathrm{H}^{+}-\mathrm{CH}_{2} \mathrm{SSO}_{2} \mathrm{CH}_{3}, 40\right), \quad 116$ (59), 87 (100\%); HRMS $m / z$ (CI-): Found 254.9996 ([M-H]-); $\mathrm{C}_{7} \mathrm{H}_{11} \mathrm{O}_{6} \mathrm{~S}_{2}$ requires 254.9997 .

3,3,4-Tricarboxybutyl methanethiosulfonate (1e). Anhydrous $\mathrm{K}_{2} \mathrm{CO}_{3}(1.2 \mathrm{~g}, 8.68 \mathrm{mmol})$ was added to a solution of Meldrum's acid (5a) (1 g, $6.94 \mathrm{mmol})$ in DMF (20 $\mathrm{mL}$ ) under $\mathrm{N}_{2}$ and stirred vigorously. After $2 \mathrm{~h}$ the supernatant liquid was added dropwise over a period of $1 \mathrm{~h} 30 \mathrm{~min}$ to a solution of tert-butylbromoacetate (1.14
$\mathrm{mL}, 7.63 \mathrm{mmol})$ in DMF (5 mL) under $\mathrm{N}_{2}$. After a further $52 \mathrm{~h}$ TLC (acetone:toluene, 1:9) indicated the conversion of starting material $\left(R_{f} 0.45\right)$ to major $\left(R_{f} 0.5\right)$ and minor $\left(R_{f} 0.8\right)$ products. The reaction mixture was added to water $(100 \mathrm{~mL})$ and extracted with ether $(100$ $\mathrm{mL} \times 3)$. The organic fractions were combined, dried $\left(\mathrm{MgSO}_{4}\right)$, filtered and the solvent removed. The residue was purified by flash chromatography (EtOAc:hexane, $3: 17$ to $1: 3)$ to give 5,5-di(tert-butoxycarbo)methyl-2,2dimethyl-1,3-dioxocyclohexa-4,6-dione (412 mg, 16\%); mp $103-105^{\circ} \mathrm{C}$ (ether:hexane); ${ }^{1} \mathrm{H} \mathrm{NMR} \mathrm{CDCl}_{3} \delta 1.41$ (s, 18H, C(CH $\left.)_{3} \times 2\right), 1.92\left(\mathrm{~s}, 6 \mathrm{H}, \mathrm{C}\left(\mathrm{CH}_{3}\right)_{2}\right), 2.97(\mathrm{~s}, 4 \mathrm{H}$, $\left.\mathrm{CH}_{2} \mathrm{COOBu}{ }^{t} \times 2\right) ;{ }^{13} \mathrm{C} \mathrm{NMR} \mathrm{CDCl}_{3} \delta 28.5\left(\mathrm{C}\left(\mathrm{CH}_{3}\right)_{3}\right)$, $29.2,44.1\left(\mathrm{CH}_{2} \mathrm{COOBu}^{t}, \mathrm{C}\left(\mathrm{CH}_{3}\right)_{2}\right) 47.2(\mathrm{C}-\overline{5}), 83.1$ $\left(\mathrm{C}\left(\mathrm{CH}_{3}\right)_{3}\right), 108.5\left(\mathrm{C}\left(\mathrm{CH}_{3}\right)_{2}\right), 168.0,168.9(\mathrm{C}-4, \mathrm{C}-6$, $\left.\overline{\mathrm{COOBu}}^{t}\right)$; and a mixture of $\mathbf{5 a}$ and 5-(tert-butoxycarbo)methyl-2,2-dimethyl-1,3-dioxocyclohexa-4,6-dione (5c). This mixture was purified by repeated crystallization from ether:hexane to give $5 \mathrm{c}(1.05 \mathrm{~g}, 59 \%)$ as a white solid; mp $124-126^{\circ} \mathrm{C}$ (ether:hexane); IR (KBr) $1772,1755,1712 \mathrm{~cm}^{-1}(\mathrm{C}=\mathrm{O}) ;{ }^{1} \mathrm{H} \mathrm{NMR}\left(\mathrm{CDCl}_{3}\right) \delta 1.43$ (s, 9H, C( $\left.\left.\mathrm{CH}_{3}\right)_{3}\right), 1.80\left(\mathrm{~s}, 6 \mathrm{H}, \mathrm{C}\left(\mathrm{CH}_{3}\right)_{2}\right), 3.09$ (d, J 4Hz, $\left.2 \mathrm{H}, \mathrm{CH}_{2} \mathrm{COOBu}^{t}\right), 3.70(\mathrm{t}, J 4 \mathrm{~Hz}, 1 \mathrm{H}, \mathrm{H}-5) ;{ }^{13} \mathrm{C} \mathrm{NMR}$ $\mathrm{CDCl}_{3} \delta$ 18.7, 28.8, 33.0, $43.4\left(\mathrm{CH}_{2} \mathrm{COOBu}^{t}, \mathrm{C}\left(\mathrm{CH}_{3}\right)_{2}\right.$, C-5), $28.5\left(\mathrm{C}\left(\mathrm{CH}_{3}\right)_{3}\right), 82.8\left(\mathrm{C}\left(\overline{\mathrm{CH}}_{3}\right)_{3}\right), 105.6\left(\mathrm{C}\left(\overline{\mathrm{CH}}_{3}\right)_{2}\right)$, 165.6, 169.6 (C)-4, C-6, COOBBu$\left.{ }^{t}\right) ; \mathrm{MS} \mathrm{m} / z$ (CI-): 257 $\left([\mathrm{M}-\mathrm{H}]^{-}, 100\right), 200(8), 1 \overline{59}$ (25) 143 (32\%).

Anhydrous $\mathrm{K}_{2} \mathrm{CO}_{3}(300 \mathrm{mg}, 2.17 \mathrm{mmol})$ was added to a solution of $5 \mathbf{c}(400 \mathrm{mg}, 1.55 \mathrm{mmol})$ in DMF $(10 \mathrm{~mL})$ under $\mathrm{N}_{2}$ and stirred vigorously. After $1 \mathrm{~h}$ the supernatant liquid was added dropwise to a solution of 1,2dibromoethane $(0.7 \mathrm{~mL}, 8.06 \mathrm{mmol})$ in DMF $(3 \mathrm{~mL})$ under $\mathrm{N}_{2}$ at $50^{\circ} \mathrm{C}$. After $70 \mathrm{~h}$, TLC (EtOAc:hexane, 1:9) indicated the conversion of starting material $\left(R_{f} 0.1\right)$ to a major product $\left(R_{f} 0.3\right)$. The reaction mixture was cooled, added to distilled water $(50 \mathrm{~mL})$ and extracted with ether $(50 \mathrm{~mL} \times 3)$. The organic fractions were combined, dried $\left(\mathrm{MgSO}_{4}\right)$, filtered and the solvent removed. The residue was purified by flash chromatography (EtOAc:hexane, 1:9) to give 5-(2'-bromoethyl)5-(tert-butoxycarbo)methyl-2,2-dimethyl-1,3-dioxocyclohexa-4,6-dione (6c) (372 mg, 66\%) as a white solid; mp $120-123^{\circ} \mathrm{C}$ (ether:hexane); IR (KBr) 1773, 1731 $\mathrm{cm}^{-1}(\mathrm{C}=\mathrm{O}) ;{ }^{1} \mathrm{H} \mathrm{NMR}\left(\mathrm{CDCl}_{3}\right) \delta 1.40\left(\mathrm{~s}, 9 \mathrm{H}, \mathrm{C}\left(\mathrm{CH}_{3}\right)_{3}\right)$, $1.80,1.93\left(\mathrm{~s} \times 2,3 \mathrm{H} \times 2, \mathrm{C}\left(\mathrm{CH}_{3}\right)_{2}\right), 2.41(\mathrm{t}, J=8 \mathrm{~Hz}$, $\left.2 \mathrm{H}, \mathrm{H}-1^{\prime}\right), 3.11\left(\mathrm{~s}, 2 \mathrm{H}, \mathrm{CHCOOBu}^{\mathrm{t}}\right), 3.32(\mathrm{t}, J=8 \mathrm{~Hz}$, $\left.2 \mathrm{H}, \mathrm{H}-2^{\prime}\right) ;{ }^{13} \mathrm{C}$ NMR $\left(\mathrm{CDCl}_{3}\right) \delta \quad 25.2,29.3,29.9$, $41.0,41.4\left(\mathrm{CH}_{2} \mathrm{COOBu}^{t}, \mathrm{C}\left(\mathrm{CH}_{3}\right)_{2}, \mathrm{C}-1^{\prime}, \mathrm{C}-2^{\prime}\right), 28.5$

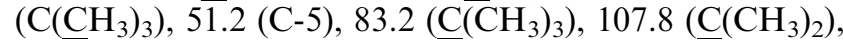
167.8, 170.2 (C-4, C-6, COOBu$\left.{ }^{t}\right)$; MS m/z (CI-): 287 (2), $257\left(\mathrm{M}-\left(\mathrm{CH}_{2}\right)_{2} \mathrm{Br}, 100\right), 142$ (15) 79, 81 (Br, 91\%).

$\mathrm{NaSSO}_{2} \mathrm{CH}_{3}(143 \mathrm{mg}, 1.07 \mathrm{mmol})$ was added to a solution of $\mathbf{6 c}(301 \mathrm{mg}, 0.82 \mathrm{mmol})$ in DMF $(20 \mathrm{~mL})$ under $\mathrm{N}_{2}$ and the resulting solution warmed to $50^{\circ} \mathrm{C}$. After $29 \mathrm{~h}$ the reaction solution was cooled and the solvent removed. The residue was purified by flash chromatography (EtOAc:hexane, 1:3) and crystallized from ether to give 2-(5'-(tert-butoxycarbo)methyl- $2^{\prime}, 2^{\prime}$-dimethyl1,3-dioxocyclohexa-4,6-dionyl)ethyl methanethiosulfonate $(7 \mathrm{c})(280 \mathrm{mg}, 86 \%)$ as a colorless crystalline solid; mp $103-105^{\circ} \mathrm{C}$ (ether:hexane); IR (KBr) 1772, 1738, 
$1717 \mathrm{~cm}^{-1}(\mathrm{C}=\mathrm{O}) 1314,1129 \mathrm{~cm}^{-1}\left(\mathrm{~S}-\mathrm{SO}_{2}\right) ;{ }^{1} \mathrm{H} \mathrm{NMR}$ $\mathrm{CDCl}_{3} \delta 1.41\left(\mathrm{~s}, 9 \mathrm{H}, \mathrm{C}\left(\mathrm{CH}_{3}\right)_{3}\right), 1.83,1.93(\mathrm{~s} \times 2,3 \mathrm{H} \times 2$, $\left.\mathrm{C}\left(\mathrm{CH}_{3}\right)_{2}\right), 2.33-2.41$ (m, 2H, H-2), 3.10-3.18 (m, 2H, H1), $3.13\left(\mathrm{~s}, 2 \mathrm{H}, \mathrm{CH}_{2} \mathrm{COOBu}^{t}\right), 3.32\left(\mathrm{~s}, 3 \mathrm{H}, \mathrm{SSO}_{2} \mathrm{CH}_{3}\right)$; ${ }^{13} \mathrm{C} \mathrm{NMR}\left(\mathrm{CDCl}_{3}\right) \delta 28.0\left(\mathrm{C}\left(\mathrm{CH}_{3}\right)_{3}\right), 28.9,29.2,30.7$, $37.9,40.2\left(\mathrm{CH}_{2} \mathrm{COOBu}^{t}, \mathrm{C}\left(\mathrm{CH}_{3}\right)_{2}, \mathrm{C}-1, \mathrm{C}-2\right), 50.0(\mathrm{C}-$ $\left.\left.5^{\prime}\right), 50.6\left(\mathrm{SSO}_{2} \mathrm{CH}_{3}\right), 82.8\left(\overline{\mathrm{C}(} \mathrm{CH}_{3}\right)_{3}\right), 107.3\left(\mathrm{C}\left(\mathrm{CH}_{3}\right)_{2}\right)$, 167.2, $169.7\left(\mathrm{C}-4^{\prime}, \mathrm{C}-6^{\prime}, \mathrm{COOBu}^{t}\right) ; \mathrm{MS} \mathrm{m} / z$ (CI-): 395 $\left([\mathrm{M}-\mathrm{H}]^{-}, 1\right), 381\left(\mathrm{M}^{-}-\mathrm{CH}_{3}, 2\right), 281\left(\mathrm{M}^{-}-\mathrm{H}-\mathrm{CH}_{2} \mathrm{COO}-\right.$ $\left.\mathrm{Bu}^{t}, 5\right), 257\left(\mathrm{M}^{-}-\left(\mathrm{CH}_{2}\right)_{2} \mathrm{SSO}_{2} \mathrm{CH}_{3}, 100\right), 215$ (45), 158 $(37 \%)$.

A solution of $7 \mathbf{c}(138 \mathrm{mg}, 0.35 \mathrm{mmol})$ in $\mathrm{CF}_{3} \mathrm{COOD}: \mathrm{D}_{2} \mathrm{O}(7: 3,2 \mathrm{~mL})$ was heated to $50^{\circ} \mathrm{C}$. After $32 \mathrm{~h},{ }^{1} \mathrm{H}$ NMR spectroscopy showed the conversion of starting material to a single product. The solution was cooled and the solvent removed. The residue was purified by flash chromatography (butan-1-ol:AcOH:water, 4:1:1) and ion exchange chromatography (Amberlyst $\mathrm{A} 21,30 \% \mathrm{v} / \mathrm{v} \mathrm{CF}_{3} \mathrm{COOH}(\mathrm{aq})$ as eluent) to give 1e (73 $\mathrm{mg}, 70 \%$ ) as an amorphous solid; IR (KBr) $1706 \mathrm{~cm}^{-1}$ $(\mathrm{C}=\mathrm{O}) 1310,1127 \mathrm{~cm}^{-1}\left(\mathrm{~S}_{-} \mathrm{SO}_{2}\right) ;{ }^{1} \mathrm{H} \mathrm{NMR}\left(\mathrm{D}_{2} \mathrm{O}\right) \delta$ 2.25-2.34 (m, 2H, H-2), 3.01 (s, 2H, H-4), 3.12-3.20 (m, $2 \mathrm{H}, \mathrm{H}-1), 3.45\left(\mathrm{~s}, 3 \mathrm{H}, \mathrm{SSO}_{2} \mathrm{CH}_{3}\right) ;{ }^{13} \mathrm{C} \mathrm{NMR}\left(\mathrm{D}_{2} \mathrm{O}\right) \delta$ $34.3,37.7,41.1$ (C-1, C-2, C-4), $52.9\left(\mathrm{SSO}_{2} \mathrm{CH}_{3}\right), 58.0$ (C-3), 177.0, 177.1 (COOH, $\left.\mathrm{CH}_{2} \mathrm{COOH}\right) ; \mathrm{MS} m / z$ (FAB-): 299 ([MH] $\left.^{-}, 42\right), 221$ (21), 183 (40), 111 (49), 91 $(100 \%)$. Anal. calcd for $\mathrm{C}_{8} \mathrm{H}_{12} \mathrm{O}_{8} \mathrm{~S}_{2}: \mathrm{C}, 32.00 ; \mathrm{H}, 4.03 \%$; found: C, 31.84; H 3.91\%;

Site-specific chemical modification. To approximately 25 $\mathrm{mg}$ of each of the SBL mutants in CHES buffer $(2.5 \mathrm{~mL}$; $70 \mathrm{mM}$ CHES, $5 \mathrm{mM}$ MES, $2 \mathrm{mM} \mathrm{CaCl}_{2}, \mathrm{pH}$ 9.5) at $20^{\circ} \mathrm{C}$ was added each of the methanethiosulfonate reagents $\left(100 \mu \mathrm{L}\right.$ of a $0.2 \mathrm{M}$ solution: $\mathbf{1 b}$ in $\mathrm{CH}_{3} \mathrm{CN}$ : $\mathrm{H}_{2} \mathrm{O}$ (1:9), 1a,c,d,e in water), in a PEG(MW 10,000)coated polypropylene test tube and mixed using an end-over-end rotator. The progress of modification was followed using specific activity measurement, monitored spectrophotometrically $(10 \mu \mathrm{L}$ aliquots in $0.1 \mathrm{M}$ Tris- $\mathrm{HCl}$ buffer, $\mathrm{pH} 8.6,0.005 \%$ Tween 80 , and $1 \%$ DMSO, with succinyl-AAPF-pNA (1 $\mathrm{mg} / \mathrm{mL})$ as substrate at $\left.25^{\circ} \mathrm{C}, \varepsilon_{410}=8800 \mathrm{M}^{-1} \mathrm{~cm}^{-1}\right)^{63}$ on a PerkinElmer Lambda 2 spectrophotometer. The reaction was terminated when the addition of a further $100 \mu \mathrm{L}$ of methanethiosulfonate solution gave no further change in specific activity, typically after 2 to $3 \mathrm{~h}$. The reaction solution was purified on a disposable desalting column (Pharmacia Biotech PD-10, Sephadex G-25 M) preequilibrated with MES buffer ( $5 \mathrm{mM}$ MES, $2 \mathrm{mM}$ $\mathrm{CaCl}_{2}, \mathrm{pH}$ 6.5). The CMM was eluted with this buffer (3.5 mL), dialyzed against MES buffer (10 mM MES, 1 $\left.\mathrm{mM} \mathrm{CaCl} \mathrm{pH}_{2} \mathrm{p}, 1 \mathrm{~L} \times 3\right)$ at $4^{\circ} \mathrm{C}$ and subsequently flash frozen and stored at $-18^{\circ} \mathrm{C}$. The free thiol content of all CMMs, was determined spectrophotometrically by titration with Ellman's reagent $\left(\varepsilon_{412}=13,600 \mathrm{M}^{-1}\right.$ $\mathrm{cm}^{-1}$ ) in phosphate buffer $0.25 \mathrm{M}, \mathrm{pH}$ 8.0. In all cases no free thiol was detected. Modified enzymes were analyzed by nondenaturing gradient $(8-25 \%)$ gels at $\mathrm{pH}$ 4.2, run towards the cathode, on the Pharmacia Phastsystem and appeared as a single band. Each of the CMMs showed reduced mobility relative to wild-type. Prior to ES-MS analysis CMMs were purified by FPLC
(BioRad, Biologic System) on a Source 15 RPC matrix (17-0727-20 from Pharmacia) with 5\% acetonitrile, $0.01 \%$ TFA as the running buffer and eluted with $80 \%$ acetonitrile, $0.01 \%$ TFA in a one step gradient. MS $m / z$ (ES-MS): N62C-a calculated 26,826, found 26,828; S156C-a ${ }^{33}$ calculated 26,853, found 26,859; S166C-a ${ }^{33}$ calculated 26,853, found 26,851; L217C-a ${ }^{31}$ calculated 26,827 , found 26,828 ; N62C-b calculated 26,819 , found 26,820; S156C-b calculated 26,846, found 26,846; S166Cb calculated 26,846, found 26,846; L217C-b calculated 26,820, found 26,820; N62C-c calculated 26,897, found 26,896; S156C-c calculated 26,924, found 26,928; S166Cc calculated 26,924, found 26,928; L217C-c calculated 26,898, found 26,904; N62C-d calculated 26,863, found 26,870; S156C-d calculated 26,890, found 26,892; S166Cd calculated 26,890, found 26,894; L217C-d calculated 26,864, found 26,866; N62C-e calculated 26,907, found 26,909; S156C-e calculated 26,934, found 26,939; S166Ce calculated 26,934, found 26,939; L217C-e calculated 26,908, found 26911 .

Active site titrations. The active enzyme concentration was determined as previously described ${ }^{47}$ by monitoring fluoride ion release upon enzyme reaction with $\alpha$-toluenesulfonyl fluoride (PMSF) as measured by a fluoride ion sensitive electrode (Orion Research 96-09). The active enzyme concentration determined in this way was used to calculate $k_{\text {cat }}$ values for each CMM except in the case of S166C-c for which total protein concentration as determined by absorbance at $280 \mathrm{~nm}\left(\varepsilon_{280}=23000 \mathrm{M}^{-1}\right.$ $\left.\mathrm{cm}^{-1}\right)^{64}$ was used. ${ }^{48}$

Kinetic measurements. Michaelis-Menten constants were measured at $25( \pm 0.2)^{\circ} \mathrm{C}$ by curve fitting $\left(\mathrm{GraFit}^{\circledR}\right.$ 3.03) of the initial rate data determined at eight or nine concentrations $(0.125-4.0 \mathrm{mM})$ of succinyl-AAPF- $p \mathrm{NA}$ substrate in $0.1 \mathrm{M}$ Tris- $\mathrm{HCl}$ buffer containing $0.005 \%$ Tween 80, 1\% DMSO, pH $8.6 \quad\left(\varepsilon_{410}=8800 \quad \mathrm{M}^{-1}\right.$ $\left.\mathrm{cm}^{-1}\right) .63$

\section{Acknowledgements}

Generous funding was provided by the Natural Sciences and Engineering Research Council of Canada (NSERC) and Genencor International Inc. who also provided SBL-WT, -N62C, -S156C, -S166C and -L217C enzymes. We also acknowledge the award of a scholarship from NSERC (to G.D.). We thank Drs. Chris Murray, Christian Paech, Thomas Graycar, and Colin Mitchinson for helpful discussions.

\section{References and Notes}

1. Hermes, J. D.; Blacklow, S. C.; Knowles, J. R. Proc. Natl. Acad. Sci. USA 1990, 87, 696.

2. El Hawrani, A. S.; Sessions, R. B.; Moreton, K. M.; Holbrook, J. J. J. Mol. Biol. 1996, 264, 97.

3. Arnold, F. Acc. Chem. Res. 1998, 31, 125.

4. Wells, J. A.; Powers, D. B.; Bott, R. R.; Graycar, T. P.; Estell, D. A. Proc. Natl. Acad. Sci. USA 1987, 84, 1219.

5. Sternberg, M. J. E.; Hayes, F. R. F.; Russell, A. J.; Thomas, P. G.; Fersht, A. R. Nature 1987, 330, 86. 
6. Cronin, C. N.; Kirsch, J. F. Biochemistry 1988, 27, 4572.

7. Blacklow, S. C.; Liu, K. D.; Knowles, J. R. Biochemistry 1991, 30, 8470 .

8. Beaumont, A.; Barbe, B.; Le Moual, H.; Boileau, G.; Crine, P.; Fournié-Zaluski, M.-C.; Roques, B. P. J. Biol. Chem. 1992, 267, 2138.

9. Bocanegra, J. A.; Scrutton, N. S.; Perham, R. N. Biochemistry 1993, 32, 2737.

10. Steinicke, H. R.; Mortensen, U. H.; Christenssen, U.; Remington, S. J.; Breddam, K. Protein Eng. 1994, 7, 911.

11. Hogan, J. K.; Pittol, C. A.; Jones, J. B.; Gold, M. Biochemistry 1995, 34, 4225.

12. Ballinger, M. D.; Tom, J.; Wells, J. A. Biochemistry 1995, $34,13312$.

13. Buchbinder, J. L.; Luong, C. B. H.; Browner, M. F.; Fletterick, R. J. Biochemistry 1997, 36, 8039.

14. Ballinger, M. D.; Tom, J.; Wells, J. A. Biochemistry 1996, 35, 13579.

15. Mansour, S. J.; Candia, J. M.; Matsuura, J. E.; Manning, M. C.; Ahn, N. G. Biochemistry 1996, 35, 15529.

16. Kurth, T.; Ullmann, D.; Jakubke, H.-D.; Hedstrom, L. Biochemistry 1997, 36, 10098.

17. Tougu, V.; Tiivel, T.; Talts, P.; Sikănis, V.; Pogarkova, S.; Kesvatera, T.; Aaaviksaar, A. Eur. J. Biochemistry 1994, 222, 475.

18. Silvestrini, M. C.; Tordi, M. G.; Citro, G.; Vecchini, P.; Brunori, M. J. Inorg. Biochemistry 1995, 57, 168.

19. Lundblad, R. L. Techniques in Protein Modification; CRC: Boca Raton, FL, 1995.

20. Cornish, V. W.; Mendel, D.; Schultz, P. G. Angew. Chem., Intl. Ed. Engl. 1995, 34, 621.

21. Karginov, V. A.; Mameav, S. V.; An, H.; van Cleve, M. D.; Hecht, S. M.; Komatsoulis, G. A.; Abelson, J. N. J. Am. Chem. Soc. 1997, 119, 8166.

22. Park, Y.; Luo, J.; Schultz, P. G.; Kirsch, J. F. Biochemistry 1997, 36, 10517.

23. Bech, L. M.; Breddam, K. Carlsberg Res. Commun. 1988 , 53,381 .

24. Smith, H. B.; Hartman, F. C. J. Biol. Chem. 1988, 263, 4921.

25. Grøn, H.; Bech, L. M.; Branner, S.; Breddam, K. Eur. J. Biochemistry 1990, 194, 897.

26. Wynn, R.; Richards, F. M. Protein Sci. 1993, 2, 395.

27. Gloss, L. M.; Kirsch, J. F. Biochemistry 1995, 34, 12323.

28. Wynn, R.; Harkins, P. C.; Richards, F. M.; Fox, R. O. Protein Sci. 1996, 5, 1026.

29. Kenyon, G. L.; Bruice, T. W. Methods Enzymol. 1977, 47, 407.

30. Wynn, R.; Richards, F. M. Methods Enzymol. 1995, 251, 351.

31. Berglund, P.; DeSantis, G.; Stabile, M. R.; Shang, X.; Gold, M.; Bott, R. R.; Graycar, T. P.; Lau, T. H.; Mitchinson, C.; Jones, J. B. J. Am. Chem. Soc. 1997, 119, 5265.

32. Stabile, M. R.; Lai, W. G.; DeSantis, G.; Gold, M.; Jones, J. B.; Mitchinson, C.; Bott, R. R.; Graycar, T. P.; Liu, C.-C. Bioorg. Med. Chem. Lett. 1996, 6, 2501.

33. DeSantis, G.; Berglund, P.; Stabile, M. R.; Gold, M.; Jones, J. B. Biochemistry 1998, 37, 5968.

34. The coordinates of SBL have been deposited at the Protein Databank at Brookhaven under the code 1JEA.

35. Nomenclature of Schechter, I.; Berger, A. Biochemistry Biophys. Res. Commun. 1967, 27, 157.

36. Douglass, I. B.; Farah, B. S. J. Org. Chem. 1959, 24, 973.

37. Levitt, L. S.; Levitt, B. W. J. Org. Chem. 1972, 37, 332.

38. Weidner, J. P.; Block, S. S. J. Med. Chem. 1972, 15, 564.

39. Palumbo, G.; Caputo, R. Synthesis 1981, 888.

40. Block, E.; Zhao, S. H. J. Org. Chem. 1992, 57, 5815.

41. Billard, T.; Langlois, B. R.; Large, S.; Anker, D.; Roidot, N.; Roure, P. J. Org. Chem. 1996, 61, 7545.
42. Baldwin, T. O.; Holzmann, T. F.; Satoh, P. S.; Yein, F. S. US Patent 4879249, 1989.

43. Arnett, E. M.; Maroldo, S. G.; Schilling, S. L.; Harrelson, J. A., Jr. J. Am. Chem. Soc. 1984, 106, 6759.

44. Arnett, E. M.; Harrelson, J. A., Jr. J. Am. Chem. Soc. 1987, 109, 809 .

45. Direct alkylation of $\mathbf{5 a}$ with 1,2-dibromoethane led only to the formation of a spirocyclopropane derivative, the product of intramolecular cyclization, in low yield. For a recent analysis of the high propensity of the anion of $\mathbf{5 a}$ to form cyclic products with $\alpha, \omega$-dihalides see Ridvan L.; Závada J. Tetrahedron 1997, 53, 14793.

46. Ellman, G. L.; Courtney, K. D.; Andres, V.; Featherstone, R. M. Biochemistry Pharmacol. 1961, 7, 88.

47. Hsia, C. Y.; Ganshaw, G.; Paech, C.; Murray, C. J. Anal. Biochemistry 1996, 242, 221.

48. Certain inconsistencies between active enzyme concentration as determined by active site titration with PMSF. ${ }^{47}$ and total protein concentration have been reported for negatively charged mutants of SBL, (Murray C.J., personal communication). These are characterized by sluggish fluoride ion concentration bursts and high rates of background PMSF hydrolysis. Active enzyme concentration values for S166C-b were low and gave rise to an anomalous value for $k_{\text {cat }}(270 \pm$ $\left.5 \mathrm{~s}^{-1}\right)$. Consequently the value shown was calculated using total protein concentration as determined by absorbance at $280 \mathrm{~nm}\left(\varepsilon_{280}=23,000 \mathrm{M}^{-1} \mathrm{~cm}^{-1}\right)$. The $K_{\mathrm{M}}$ value determined $(1.52 \pm 0.06 \mathrm{mM})$ is not concentration dependent.

49. The following kinetic parameters for the previously prepared $^{31,33}$ near isosteric CMMs were determined under the conditions described in the experimental section; N62C-Sethyl $k_{\text {cat }} 104 \pm 2 \mathrm{~s}^{-1}, K_{\mathrm{M}} 0.55 \pm 0.04 \mathrm{mM}, k_{\text {cat }} / K_{\mathrm{M}} 189 \pm 14$ $\mathrm{s}^{-1} \mathrm{mM}^{-1}$; N62C-S-benzyl $k_{\text {cat }} 129 \pm 3 \mathrm{~s}^{-1}, K_{\mathrm{M}} 0.34 \pm 0.03$ $\mathrm{mM}, k_{\text {cat }} / K_{\mathrm{M}} 379 \pm 37 \mathrm{~s}^{-1} \mathrm{mM}^{-1} ; \mathrm{N} 62 \mathrm{C}-S$ - $n$-pentyl $k_{\text {cat }} 184 \pm 5$ $\mathrm{s}^{-1}, K_{\mathrm{M}} 0.75 \pm 0.05 \mathrm{mM}, k_{\text {cat }} / K_{\mathrm{M}} 245 \pm 18 \mathrm{~s}^{-1} \mathrm{mM}^{-1} ; \mathrm{L} 217 \mathrm{C}-$ $S$-n-pentyl $k_{\text {cat }} 87 \pm 3 \quad \mathrm{~s}^{-1} ; \quad K_{\mathrm{M}} \quad 0.52 \pm 0.05 \mathrm{mM}, \quad k_{\text {cat }} / K_{\mathrm{M}}$ $167 \pm 17 \mathrm{~s}^{-1} \mathrm{mM}^{-1} ; \quad$ S156C-S-benzyl $k_{\text {cat }} 72 \pm 2 \mathrm{~s}^{-1} ; K_{\mathrm{M}}$ $0.59 \pm 0.05 \mathrm{mM}, k_{\mathrm{cat}} / K_{\mathrm{M}} 122 \pm 11 \mathrm{~s}^{-1} \mathrm{mM}^{-1} ; \mathrm{S} 166 \mathrm{C}-S$-ethyl $k_{\text {cat }} 11.8 \pm 0.5 \mathrm{~s}-1 ; K_{\mathrm{M}} 0.76 \pm 0.08 \mathrm{mM}, k_{\text {cat }} / K_{\mathrm{M}} 15.5 \pm 1.8$ $\mathrm{s}^{-1} \mathrm{mM}^{-1} ; \mathrm{S} 166 \mathrm{C}-S$-benzyl $k_{\text {cat }} 23.1 \pm 0.5 \mathrm{~s}^{-1} ; K_{\mathrm{M}} 1.17 \pm 0.06$ $\mathrm{mM}, k_{\text {cat }} / K_{\mathrm{M}} 19.7 \pm 1.1 \mathrm{~s}^{-1} \mathrm{mM}^{-1}$.

50. Jackson, S. E.; Fersht, A. R. Biochemistry 1993, 32, 13919. 51. Estell, D. A.; Graycar, T. P.; Miller, J. V.; Powers, D. B.; Burnier, J. P.; Ng, P. G.; Wells, J. A. Science 1986, 233, 659.

52. This space is more limited in SBL than in subtilisin $\mathrm{BPN}^{\prime}$ as the peptide backbone that makes up the wall of the $S_{1}$ pocket contains four less amino acid residues.

53. Akabas, M. H.; Stauffer, D. A.; Xu, M.; Karlin, A. Science 1992, 258, 307.

54. Akabas, M.H; Kaufman, C.; Archdeacon, P.; Karlin, A. Neuron 1994, 13, 919.

55. Akabas, M. H.; Kaufman, C.; Cook, T. A.; Archdeacon, P. J. Biol. Chem. 1994, 269, 14865.

56. Cheung, M.; Akabas, M. H. J. Gen. Physiol. 1997, 109, 289. 57. Stauffer, D. A.; Karlin, A. Biochemistry 1994, 33, 6840.

58. Yang, N.; George, A. L., Jr.; Horn, R. Neuron 1996, 16, 113.

59. Holmgren, M.; Liu, Y.; Xu, Y.; Yellen, G. Neuropharmacol. 1996, 35, 797.

60. Huynh, P. D.; Cui, C.; Zhan, H. J.; Oh, K. J.; Collier, R. J.; Finklestein, A. J. Gen. Physiol. 1997, 110, 229.

61. Rassendren, F.; Buell, G.; Newbolt, A.; North, R. A.; Surprenant, A. EMBO J. 1997, 16, 3446.

62. Fittig, R.; von Furtenbach, E. Justus Liebigs Anal. Chem. 1868, 147, 292.

63. Bonneau, P. R.; Graycar, T. P.; Estell, D. A.; Jones, J. B. J. Am. Chem. Soc. 1991, 119, 1026.

64. Grøn, H.; Bech, L. M.; Branner, S.; Breddam, K. Eur. J. Biochemistry 1990, 194, 897. 